\title{
Prediction Of Problematic Internet Use By Attachment In University Students
}

\author{
Hatice Irem Ozteke Kozan ${ }^{1}$, Sahin Kesici ${ }^{1}$, Cagla Girgin Buyukbayraktar ${ }^{2}$, S. Barbaros Yalcin ${ }^{1}$ \\ ${ }^{1}$ School of Education, Necmettin Erbakan University, Konya, Turkey \\ ${ }^{2}$ College of Applied Science, Selcuk University, Beysehir-Konya, Turkey \\ Correspondence: Hatice Irem Ozteke Kozan, School of Education, Necmettin Erbakan University, Konya, Turkey.
}

Received: November 14, 2016

Accepted: December 9, 2016 Online Published: December 13, 2016

doi:10.11114/jets.v5i1.2070

URL: http://dx.doi.org/10.11114/jets.v5i1.2070

\begin{abstract}
Aim of this research is to examine the predictive power of attachment style on problematic internet use among university students. Participants of study consist of 481 university students ( 230 girls). Results indicate that there is a negative correlation between secure attachment style and social benefit/social comfort and there is a positive correlation between preoccupied attachment style and social benefit/social comfort which is a sub-dimension of problematic internet use. Considering predictive power of attachment on problematic internet use, results show that preoccupied, secure and dismissing attachment styles are significant predictors of social benefit/social comfort. Results and comments for the future studies on problematic internet use and attachment were discussed in general.
\end{abstract}

Keywords: attachment, problematic internet use, university students

\section{Introduction}

One of the main notions in understanding close relationships is the attachment theory (Hazan \& Shaver, 1994) which makes a reference to seek proximity with a specific figure in certain situations (Bowlby, 1969, 1982). In this theory, when individuals feel distressed they seek proximity to their attachment figure. If the attachment figure is available, the resulting contact alleviates distress (Selcuk, Zayas, Gunaydin, Hazan, \& Kross, 2012). The attachment system seems to have evolved to protect infants from danger by keeping them close to the mother figure (Hazan \& Shaver, 1987). In their model, Bartholomew and Horowitz (1991) proposed four attachment styles in adult attachment: The first one is secure attachment style which refers to a sense of worthiness. The second is preoccupied attachment which refers to unworthiness of the self and/or less positive view about themselves while they have a positive evaluations of others. The third one is fearful attachment which can be defined as the untrustworthy expectations about others. Lastly, rejecting and dismissing attachment style which is described as maintaining a sense of independence instead of developing close relationships.

The bond between child and parents has an everlasting effect in the adulthood and shapes their future behaviors. In adulthood and adolescence, the attachment behavior is directed to other people and groups (Bowlby, 1969, 1982). In that point, it may be assumed that attachment has a significant influence on people's social life. Attachment has been studied with various variables in the literature such as depression (e.g. Feeney, Alexander, Noller, \& Hohaus, 2003; Wei, Shaffer, Young, \& Zakalik, 2005), perfectionism (e.g. Rice \& Mirzadeh, 2000; Ozteke \& Kesici, 2015; Wei, Mallinckrodt, Russell, \& Abraham, 2004) and relationship satisfaction (e.g. Butzer \& Campbell, 2008; Kachadourian, Fincham, \& Davila, 2004). Problematic internet use has also been studied with attachment in the literature usually in recent years (e.g. Lei \& Wu, 2007; Schimmenti, Guglielmucci, Barbasio, \& Granieri, 2012; Schimmenti, Passanisi, Gervasi, Manzella, Fama, 2014).

For decades, internet has become a crucial factor on the social life of people as a consequence of rapid developments and changes in the world (Orchard \& Fullwood, 2009). This also brings many requirements for psychological adjustments in the lifestyle of people. Problematic internet use is defined as a use of internet that causes problems and difficulties in social, psychological and business life by Beard and Wolf (2001). Similar explanation for problematic internet use were made by Shapira, Goldsmith, Keck, Khosla and McElroy (2000) as one's inability of control his or her internet use and which causes impairments on his daily functions. Problematic internet use has been studied with several subjects in psychology such as career indecision (e.g. Lehman \& Knstam, 2010), risk-taking behavior (e.g. 
Odaci, 2013), shyness (e.g. Ebeling-Witte, Frank, \& Lester, 2007; Odaci \& Celik, 2013), social anxiety (e.g. Caplan, 2007), aggression (e.g. Odaci \& Celik, 2013), personality traits (e.g. Orchard \& Fulwood, 2010; Ozturk \& Ozmen, 2011) as well as studies on attachment (e.g. Odaci \& Cikrikci, 2014; Schimetti et al., 2012; Shin, Kim, Jang, 2011). These researches present how attachment and other notions, which are mentioned above, in psychology have an impact on problematic internet use. In this point, the impact of attachment cannot be ignored on problematic internet use. From this perspective, the aim of this study is to examine the associations and predictive power of attachment on problematic internet use.

\section{Method}

\subsection{Participants}

In Turkey, 481 (230 women) university students participated to this study. After receiving approval from the Faculty Review Board, Data were collected from the voluntary students at Necmettin Erbakan University.

\subsection{Instruments}

\subsubsection{The Problematic Internet Use Scale (PIUS):}

The Problematic Internet Use Scale is comprised of 33 items which was developed by Ceyhan, Ceyhan, and Gurcan (2007). The scale consists of three subscales named as negative results of the internet, social benefit/social comfort and overuse. In the scale high points refers to unhealthy internet use and internal consistency coefficient of the scale was found as 0.94 (Ceyhan et al., 2007).

\subsubsection{Relationships Scale Questionnaire}

RSQ was developed by Griffin \& Bartholomew (1994) and Turkish adaptation was made by Sumer \& Gungor (1999). Scale comprise of 17 items and aim to measure four attachment styles as -secure, preoccupied-fearful and dismissing-. Items are assessed on a Likert type scale ranging from 1 to 7.

\subsection{Data Analysis}

Pearson correlation analysis was used to reveal the relationship between attachment styles and problematic internet use. Then with stepwise regression analysis, the predictive power of attachment styles on problematic internet use was propounded.

\section{Results}

Correlation analysis results indicate that secure attachment style is negatively correlated with social benefit/social comfort in a significant level $(-.09, \mathrm{p}<.05)$. There is a positive and significant correlation between preoccupied attachment style and social benefit/social comfort (.11, $\mathrm{p}<.05)$.

Table 1. Correlation Analysis of Attachment Styles and Problematic Internet Use

\begin{tabular}{|c|c|c|c|c|c|c|c|}
\hline & 1 & 2 & 3 & 4 & 5 & 6 & 7 \\
\hline \multicolumn{8}{|l|}{ Attachment Style } \\
\hline 1.Fearful & 1 & $.16 * *$ & $-.39 * *$ & -.05 & .05 & .06 & .07 \\
\hline 2.Dismissing & & 1 & $.09 *$ & $.22 * *$ & -.04 & -.07 & .00 \\
\hline 3.Secure & & & 1 & .07 & -.08 & $-.09 *$ & -.06 \\
\hline 4. Preoccupied & & & & 1 & .07 & $.11 *$ & .06 \\
\hline \multicolumn{8}{|l|}{ Problematic Internet Use } \\
\hline 5.Overuse & & & & & 1 & $.58 * *$ & $.65^{* *}$ \\
\hline 6.Social benefit/social comfort & & & & & & 1 & $.77 * *$ \\
\hline 7.Negative results of internet & & & & & & & 1 \\
\hline
\end{tabular}

Stepwise regression analysis revealed that attachment styles are a significant predictor of problematic internet use in university student sample. Results indicate that, preoccupied attachment style predicts $11 \%$ of the variance in social benefit/ social comfort. This attachment style predicts $19 \%$ of the variance in same variable with secure attachment. With secure and dismissing attachment styles preoccupied attachment explains $26 \%$ of the variance in social benefit/ social comfort in university student sample.

Table 2. Stepwise Regression Analysis Predicting Problematic Internet Use

\begin{tabular}{lllllll}
\hline Model & $\mathbf{R}$ & $\mathbf{R}^{2}$ & $\mathbf{R}^{2}$ (Adj) & S.E. & F & P \\
\hline A & .113 & .013 & .011 & 7.31617 & 6.163 & .01 \\
B & .152 & .023 & .019 & 7.28475 & 5.679 & .00 \\
C & .179 & .032 & .026 & 7.25992 & 5.237 & .00 \\
\hline
\end{tabular}


A: Preoccupied
B: Preoccupied, Secure
C: Preoccupied, secure, Dismissing

\section{Discussion}

The current study demonstrates the associations between attachments styles and problematic internet use in university sample. Correlation analysis indicates that, while there is a negative relationship between secure attachment style and problematic internet use- contrary to the findings of Odaci and Cikrikci (2014) which they report there was no significant relations between these variables- there reveals a positive relationship between preoccupied attachment style and problematic internet use which is similar to study of Odaci and Cikrikci (2014). Also, in their study they also found that dismissing attachment style is a significant predictor of problematic internet use which has some similarities with this current study. In this study preoccupied, secure and dismissing attachment styles are significant predictors of problematic internet use. In another study which examines Facebook use from attachment perspective, Oldmeadow, Quinn and Kowert (2012) discovered that people with high attachment anxiety used Facebook more, which supports current study findings. Senormanci, Senormanci, Guclu and Korkan (2014) revealed that patients with internet addiction have more anxious attachment styles and this is another study which is similar to our findings. Shin et al. (2011) reported that both avoidant and anxious attachment style explain problematic internet use. Schimmenti et al. (2014) found that individuals higher in problematic internet use scores also were discovered to be higher in attachment insecurity scores in their study. Lei and $\mathrm{Wu}$ (2007) found that positive relationships such as trust and acceptance are important predictors of internet use of adolescents.

The current study findings have similar results with the researches which were held before in the literature. As a recommendation for future studies, problematic internet use and attachment would be studied with different variables. In clinical samples, more studies would be conducted considering attachment insecurity and internet related psychological problems. Attachment-based approaches would be included in counselors' and psychologists' sessions in preventing internet addiction and problematic use of internet.

\section{References}

Bartholomew, K., \& Horowitz, L. M. (1991). Attachment styles among young adults: a test of a four-category model. Journal of Personality and Social Psychology, 61(2), 226-244. https://doi.org/10.1037/0022-3514.61.2.226

Beard, K. W., \& Wolf, E. M. (2001). Modification in the proposed diagnostic criteria for Internet addiction. CyberPsychology \& Behavior, 4(3), 377-383. https://doi.org/10.1089/109493101300210286

Bowlby, J. (1969). Attachment and loss, volume i: Attachment.

Bowlby, J. (1982). Attachment (2nd ed.). New York: Basic Books.

Butzer, B., \& Campbell, L. (2008). Adult attachment, sexual satisfaction, and relationship satisfaction: A study of married couples. Personal Relationships, 15(1), 141-154. https://doi.org/10.1111/j.1475-6811.2007.00189.x

Caplan, S. E. (2007). Relations among loneliness, social anxiety, and problematic Internet use. CyberPsychology \& Behavior, 10(2), 234-242. https://doi.org/10.1089/cpb.2006.9963

Ceyhan, E., Ceyhan, A. A., \& Gurcan, A. (2007). Problemli İnternet Kullanımı Ölçeği’nin geçerlik ve güvenirlik çalışmaları. Kuram ve Uygulamada Eğitim Bilimleri Dergisi, 7, 387-416.

Ebeling-Witte, S., Frank, M. L., \& Lester, D. (2007). Shyness, internet use, and personality. CyberPsychology \& Behavior, 10(5), 713-716. https://doi.org/10.1089/cpb.2007.9964

Feeney, J., Alexander, R., Noller, P., \& Hohaus, L. (2003). Attachment insecurity, depression, and the transition to parenthood. Personal Relationships, 10(4), 475-493. https://doi.org/10.1046/j.1475-6811.2003.00061.x

Griffin, D. W., \& Bartholomew, K. (1994). Models of the self and other: Fundamental dimensions underlying measures of adult attachment. Journal of Personality and Social Psychology, 67(3), 430-445. https://doi.org/10.1037/0022-3514.67.3.430

Hazan, C., \& Shaver, P. R. (1987). Romantic love conceptualized as an attachment process. Journal of Personality and Social Psychology, 52(3), 511-524. https://doi.org/10.1037/0022-3514.52.3.511

Hazan, C., \& Shaver, P. R. (1994). Attachment as an organizational framework for research on close relationships. Psychological Inquiry, 5(1), 1-22. https://doi.org/10.1207/s15327965pli0501_1

Kachadourian, L. K., Fincham, F., \& Davila, J. (2004). The tendency to forgive in dating and married couples: The role of attachment and relationship satisfaction. Personal Relationships, 11(3), 373-393. 
https://doi.org/10.1111/j.1475-6811.2004.00088.x

Lehmann, I. S., \& Konstam, V. (2011). Growing up perfect: Perfectionism, problematic Internet use, and career indecision in emerging adults. Journal of Counseling \& Development, 89(2), 155-162. https://doi.org/10.1002/j.1556-6678.2011.tb00073.x

Lei, L., \& Wu, Y. (2007). Adolescents' paternal attachment and Internet use. CyberPsychology\& Behavior, 10(5), 633-639. https://doi.org/10.1089/cpb.2007.9976

Odaci, H. (2013). Risk-taking behavior and academic self-efficacy as variables accounting for problematic internet use in adolescent university students. Children and Youth Services Review, 35(1), 183-187. https://doi.org/10.1016/j.childyouth.2012.09.011

Odaci, H., \& Celik, Ç. B. (2013). Who are problematic internet users? An investigation of the correlations between problematic internet use and shyness, loneliness, narcissism, aggression and self-perception. Computers in Human Behavior, 29(6), 2382-2387. https://doi.org/10.1016/j.chb.2013.05.026

Odaci, H., \& Cikrikci, Ö. (2014). Problematic internet use in terms of gender, attachment styles and subjective well-being in university students. Computers in Human Behavior, 32, 61-66. https://doi.org/10.1016/j.chb.2013.11.019

Oldmeadow, J. A., Quinn, S., \& Kowert, R. (2013). Attachment style, social skills, and Facebook use amongst adults. Computers in Human Behavior, 29(3), 1142-1149. https://doi.org/10.1016/j.chb.2012.10.006

Orchard, L. J., \& Fullwood, C. (2010). Current perspectives on personality and Internet use. Social Science Computer Review, 28(2), 155-169. https://doi.org/10.1177/0894439309335115

Ozteke, H.I. \& Kesici, S. (2015). The prediction of romantic relationship perfectionism by attachment, mate selection myths and body image coping strategies (Unpublished doctoral dissertation). Necmettin Erbakan University Educational Science Institute, Konya.

Ozturk, E., \& Ozmen, S. K. (2011). An investigation of the problematic internet use of teacher candidates based on personality types, shyness and demographic factors. Educational Sciences: Theory \& Practice, 11(4), 1799-1808.

Rice, K. G., \& Mirzadeh, S. A. (2000). Perfectionism, attachment, and adjustment. Journal of Counseling Psychology, 47(2), 238-250. https://doi.org/10.1037/0022-0167.47.2.238

Schimmenti, A., Guglielmucci, F., Barbasio, C., \& Granieri, A. (2012). Attachment disorganization and dissociation in virtual worlds: a study on problematic internet use among players of online role playing games. Clinical Neuropsychiatry, 9(5), 195-202.

Schimmenti, A., Passanisi, A., Gervasi, A. M., Manzella, S., \& Fama, F. I. (2014). Insecure attachment attitudes in the onset of problematic Internet use among late adolescents. Child Psychiatry \& Human Development, 45(5), 588-595. https://doi.org/10.1007/s10578-013-0428-0

Selcuk, E., Zayas, V., Günaydin, G., Hazan, C., \& Kross, E. (2012). Mental representations of attachment figures facilitate recovery following upsetting autobiographical memory recall. Journal of Personality and Social Psychology, 103(2), 362-378. https://doi.org/10.1037/a0028125

Senormanci, O., Senormanci, G., Guclu, O., \& Konkan, R. (2014). Attachment and family functioning in patients with internet addiction. General Hospital Psychiatry, 36(2), 203-207.

https://doi.org/10.1016/j.genhosppsych.2013.10.012

Shapira, N. A., Goldsmith, T. D., Keck Jr, P. E., Khosla, U. M., \& McElroy, S. L. (2000). Psychiatric features of individuals with problematic internet use. Journal of Affective Disorders, 57(1), 267-272.

https://doi.org/10.1016/S0165-0327(99)00107-X

Shin, S. E., Kim, N. S., \& Jang, E. Y. (2011). Comparison of problematic internet and alcohol use and attachment styles among industrial workers in Korea. Cyberpsychology, Behavior, and Social Networking, 14(11), 665-672. https://doi.org/10.1089/cyber.2010.0470

Sumer, N., \& Gungor, D. (1999). The psychometric assessment of adult attachment styles scales on Turkish sample and a cross-cultural comparison. Turkish Journal of Psychology, 14(43), 71-106.

Wei, M., Mallinckrodt, B., Russell, D. W., \& Abraham, W. T. (2004). Maladaptive perfectionism as a mediator and moderator between adult attachment and depressive mood. Journal of Counseling Psychology, 51(2), 201-212. https://doi.org/10.1037/0022-0167.51.2.201

Wei, M., Shaffer, P. A., Young, S. K., \& Zakalik, R. A. (2005). Adult attachment, shame, depression, and loneliness: The 
mediation role of basic psychological needs satisfaction. Journal of Counseling Psychology, 52(4), 591-601. https://doi.org/10.1037/0022-0167.52.4.591

\section{Notes}

Note 1. This study has been presented in "World Conference on Psychology Sciences" in Las Vegas, USA on July 13-14 2014 as an oral presentation.

\section{Copyrights}

Copyright for this article is retained by the author(s), with first publication rights granted to the journal.

This is an open-access article distributed under the terms and conditions of the Creative Commons Attribution license which permits unrestricted use, distribution, and reproduction in any medium, provided the original work is properly cited. 